\title{
Editorial: European water framework directive
}

1 Michael Hartnett PhD, CEng, FIEI

Senior Lecturer, Civil Engineering Department, National University of Ireland, Galway, Ireland
2 Anastasios I. Stamou Dipl. Eng, MSc, PhD, DiC Professor, National Technical University of Athens, Greece
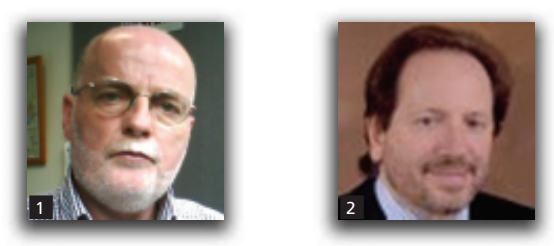

The EU water framework directive (WFD) has been one of the most significant legislative drivers with respect to water policy in recent times. The directive established a framework for community action in the pursuit of good ecological status for all waters in EU member states. Since its publication, member states have invested significant amounts of resources into research projects and in developing new national policies. Also during the early implementation stages of the WFD there has been a considerable amount of transnational collaborations bringing experts from different countries together to solve common problems.

When member states began the process of implementing the directive over 10 years ago individual states had widely differing national legislation and monitoring practices; thus over the intervening 10-year period member states have taken different routes in order to achieve good ecological status in river basins. Some member states have had to substantially enhance water quality monitoring programmes in order to ensure compliance with the directive, while other countries have had to make relatively few changes to existing monitoring programmes. With the establishment of river basin management plans each member state has had to prepare detailed, specific plans for each river basin district within their country. These plans include the programmes of measures needed to pursue the priority objective of achieving good water status by 2015 . We are now only 2 years away from knowing if these detailed plans will deliver the desired outcome.

This special issue of Water Management highlights some of the technical solutions that have been devised to implement the directive and some of the different approaches adopted in member states.

Zalewski (2011) demonstrates that ecohydrology provides a systemic approach, which can increase the efficiency and effectiveness of implementation of the WFD, thus helping to accelerate the achievement of 'good ecological status' of water bodies. This approach consists of three steps corresponding to the basic principles of ecohydrology (a) hydrological (information on the abiotic structure of a river basin, dynamics of hydrological processes and spatial temporal specifics of anthropogenic impacts)

(b) ecological (the potential for basin resilience enhancement)

(c) ecotechnological (the use of information and knowledge for the development of new ecological biotechnologies and system solutions)

The author notes that the proposed approach requires calibration for different regions due to differences in climate, geomorphology, human impact and cultural heritage.

The paper by Bleninger and Jirka (2011) focuses on the analysis of existing mixing zone regulations and recommends procedures to define and manage mixing zone definitions as required by the WFD. EU countries are required to develop mixing zone regulations and define mixing zone extensions for point source discharges into their inland and coastal water bodies until 2010. This can be facilitated with the use of proper mathematical models. The authors present results from a survey demonstrating that only a few mixing zone regulations exist and some discharge technologies have not been yet considered. The authors analyze the discharge characteristics of brine and recommend mixing zone regulations, and also present river diffuser discharge technologies and procedures for demonstrating compliance of discharges that employ these technologies.

The paper by Estrela (2011) provides a comprehensive overview of implementation of the WFD in Spain. A key issue when developing the river basin management plans for Spain was the allocation of the available water resources, particularly in regions prone to drought. The Spanish experience has been positive as it has seen the implementation of the directive as an opportunity to incorporate many environmental issues into the new river basin management plans. Also, a greater coordination between Spanish organisations has been attained, especially between continental and coastal water authorities.

In the next paper Safiolea et al. (2011) present recent techno- 
logical developments in the field of hydro-informatics that facilitate the integrated modelling required by the WFD. The authors describe and test the open modelling interface (OpenMI), an EU modelling standard allowing models built by different developers to communicate at runtime. Safiolea et al. illustrate the potential of OpenMI to propose a flexible, component-based approach to building integrated models supporting the WFD implementation. The paper offers an interesting outlook on the future directions of environmental modelling, based on the rapid evolution of web services, online data repositories and open modelling standards.

Hartnett et al. (2011) consider aspects of the implementation of the WFD in the Republic of Ireland. Prior to the WFD the monitoring and reporting of water quality issues in Ireland was disparate and fragmented. In order to ensure compliance many government agencies were forced to work together to devise consistent plans. Considerable amounts of research funding were provided by the Irish EPA to provide a basis for the more indepth monitoring and analysis. Much of the research focused on developing monitoring systems that would be representative of the water bodies in question. Modelling and statistical tools were found to provide the best platform for developing accurate monitoring programmes.

The paper by Newson (2011) broadens the scope of the topics considered in this special issue. Newson considers the potential role of the third-sector (river trusts charities) in co-delivering the WFD. The aim of this paper is to consider how the third sector can provide public engagement and help consider the WFD within a 'big society' political context. The Tyne Rivers Trust (TRT) is used as a case study; TRT engages in several ways such as education, debates and voluntary work. The case study describes how the TRT is on the Northumbria river basin district liaison panel; this is a significant positive step for the trust, but also brings responsibility.
The six papers published in this special issue provide interesting overviews of many aspects of the implementation of the water framework directive and many of the new ideas that have developed in the relatively short time since the directive was published. It is clear that water management has taken a major step forward throughout Europe. It is also clear that research will continue for many years to come to ensure more efficient solutions for compliance with water regulations and Water Management will continue to feature the significant developments in the future.

\section{REFERENCES}

Bleninger T and Jirka GH (2011) Mixing zone regulation for effluent discharges into EU waters. Proceedings of the Institution of Civil Engineers, Water Management 164(8): 387-396, doi: 10.1680/wama.900037.

Estrela T (2011) The EU WFD and the river basin management plans in Spain. Proceedings of the Institution of Civil Engineers, Water Management 164(8): 397-404, doi: 10.1680 /wama. 1000005 .

Hartnett M, Dabrowski T and McGovern J (2011) Modelling and monitoring towards 'ecologically good' status. Proceedings of the Institution of Civil Engineers, Water Management 164(8): 421-431, doi: 10.1680/wama.2011.164.8.421.

Newson M (2011) Rivers in trust: stakeholders and delivery of the EU water framework directive. Proceedings of the Institution of Civil Engineers, Water Management 164(8): 433-440, doi: 10.1680/wama.2011.164.8.433.

Safiolea E, Baki S, Makropoulos C et al. (2011) Integrated modelling for river basin management planning. Proceedings of the Institution of Civil Engineers, Water Management 164(8): 405-419, doi: 10.1680/wama.2011.164.8.405.

Zalewski M (2011) Ecohydrology for implementation of the EU water framework directive. Proceedings of the Institution of Civil Engineers, Water Management 164(8): 375-385, doi: $10.1680 /$ wama.1000030. 